\title{
Konsep Diri Remaja dalam Komunikasi Sosial melalui "Smartphone"
}

\author{
${ }^{1}$ YENNI YUNIATI, ${ }^{2}$ ANI YUNINGSIH, ${ }^{3}$ NURAHMAWATI \\ 1, 2, 3 Fakultas IImu Komunikasi Universitas Islam Bandung, Jl. Tamansari No.1 Bandung \\ ${ }^{1}$ yenniybs@yahoo.co.id, 2 yuningsihani@yahoo,com, ${ }^{3}$ nurrahmawati10@gmail.com
}

\begin{abstract}
Smartphone usage is growing among teenagers especially junior high school students, these phenomenon cause a variety of changes in attitudes and behavior among teenagers themselves. One of smartphone strength compare to another mobile phone is the number of available features which make the smartphone has an appeal. This article used a qualitative approach seeks to look, observe, explore and experience the informant awareness regarding the use of a smartphone as a phenomenon. Aiming to gain an understanding and describe the reality regarding construction of meaning process as an adolescent self-concept. Phenomenological approach assumes, a phenomenon is an absorbed consciously experience, involving motif that seeks to examine individual consciousness based on its experience. Results of the study revealed that the use of smartphones by teenagers considered to always be able to express themselves through the features found in their smartphones. Their motives in using smartphones are to socialize, mingle, insightful, self-existence, to facilitate communication, and considered themselves to be an easy going person.
\end{abstract}

Keywords: adolescents, smartphones, self-concept and phenomenology

\begin{abstract}
Abstrak. Penggunaan smartphone atau telepon pintar semakin berkembang di kalangan remaja, terutama siswa Sekolah Menengah Pertama. Ini menimbulkan berbagai macam perubahan sikap dan perilaku di kalangan remaja itu sendiri. Salah satu fitur yang menjadi kelebihan smartphone dari handphone-handphone lainnya adalah banyaknya fitur yang tersedia membuat smartphone memiliki daya tarik. Tulisan ini menggunakan pendekatan kualitatif, berupaya melihat, mengamati, mengeksplorasi pengalaman dan kesadaran informan melalui penggunaan smartphone sebagai suatu fenomena. Bertujuan memperoleh pemahaman dan menggambarkan realitas proses konstruksi makna sebagai konsep diri remaja. Pendekatan fenomenologi mengasumsikan, fenomena adalah pengalaman yang diserap secara sadar, melibatkan motif yang berupaya menelaah tentang kesadaran individu berdasarkan pengalaman yang dimilikinya. Hasil penelitian mengungkapkan, penggunaan smartphone dianggap selalu bisa mengekspresikan dirinya melalui fitur-fitur yang terdapat dalam smartphone. Motif mereka menggunakan smartphone, antara lain, untuk sosialisasi diri, bergaul, membuka wawasan, eksistensi diri dan dapat mempermudah berkomunikasi dan dianggap sebagai orang yang mudah bergaul.
\end{abstract}

Kata kunci : remaja, smartphone, konsep diri dan fenomenologi.

\section{Pendahuluan}

Penggunaan smartphone atau telepon pintar semakin berkembang di kalangan remaja, terutama siswa Sekolah Menengah Pertama (SMP). Ini menimbulkan berbagai macam perubahan sikap dan perilaku di kalangan remaja itu sendiri. Remaja lebih memilih untuk berkomunikasi dengan teman- teman yang berada di dalam satu smartphone dengannya, daripada berkomunikasi dengan teman yang ada di sebelahnya. Beberapa kalangan berpendapat bahwa adanya smartphone ini "menjadikan teman yang jauh menjadi dekat dan teman yang dekat menjadi jauh."

Dinamika smartphone yang telah

Received: 24 Agustus 2015, Revision: 14 Oktober 2015, Accepted: 31 Desember 2015

Print ISSN: 0215-8175; Online ISSN: 2303-2499. Copyright@2015. Published by Pusat Penerbitan Universitas (P2U) LPPM Unisba Terakreditasi SK Kemendikbud, No.040/P/2014, berlaku 18-02-2014 s.d 18-02-2019 
menjadi kebutuhan primer untuk menjalin komunikasi yang cepat dikalangan masyarakat khususnya remaja, menjadikan smartphone tersebut telah bergeser fungsinya, yang awalnya merupakan kebutuhan sekunder menjadi kebutuhan primer.

Kemajuan teknologi yang disebabkan oleh meningkatnya kebutuhan akan arus informasi membuat semakin banyak digunakannya teknologi komunikasi. Smartphone merupakan salah satu dari teknologi komunikasi yang membantu manusia untuk mendapatkan informasi secara cepat. Di samping untuk membantu mencari informasi, smartphone juga berfungsi menyebarkan informasi, sehingga dengan berkembangnya kemajuan teknologi komunikasi, berkembang pula penggunaan smartphone.

Teknologi berkembang sangat pesat seiring dengan berjalannya waktu. Semakin lama, manusia pun semakin dimanjakan dengan adanya penemuan-penemuan baru dalam teknologi. Di era yang serba modern ini, teknologi semakin hari semakin berkembang dan menjadikan teknologi sebagai salah satu bagian penting bagi kehidupan manusia. Kemajuan teknologi tersebut, menimbulkan inovasi-inovasi yang mengubah banyak aspek dalam kegiatan manusia. Salah satu aspek tersebut adalah aspek komunikasi.

Dalam kehidupan sehari-harinya, manusia pasti melakukan komunikasi, dan seiring dengan berkembangnya kemajuan teknologi ini, maka muncul pula cara-cara baru untuk berkomunikasi. Perkembangan teknologi juga telah memunculkan komunikasi baru dalam bentuk Computer Mediated Communication (CMC).

Selain dapat digunakan untuk telepon dan pesan singkat seperti halnya telepon biasa, fasilitas dan kemudahan yang ada dalam smartphone, yang kemudian menarik para remaja untuk menggunakan handphone ini. Salah satu fitur yang menjadi kelebihan smartphone dari handphone-handphone lainnya adalah banyaknya fitur yang tersedia. Ini yang membuat smartphone memiliki daya tarik yang cukup tinggi, seperti fasilitas chatting atau fasilitas percakapan singkat melalui WhatsApp, Line, Twitter, Instagram, Youtube, dan lain-lain.

Dengan berbagai fasilitas ini, maka pengguna dapat mengirim pesan singkat, mengirim gambar, data, melakukan percakapan secara berkelompok atau conference, mengirimkan pesan suara maupun mengirimkan lokasi dimana kita berada. Fasilitas lain dari smartphone misalnya, fasilitas push e-mail (mengirimkan pesan elektronik dengan jaringan internet), browsing (penjelajahan dunia maya dengan jaringan internet), hiburan seperti pemutaran musik maupun video, kamera dan juga kemampuan penyimpanan data yang hampir mirip seperti yang terdapat pada komputer.

Berdasarkan uraian tersebut, maka penulisan ini memfokuskan mengenai bagaimana konsep diri siswa sekolah menengah pertama negeri Kota Bandung dalam komunikasi sosial melalui teknologi komunikasi.

\section{Studi Kepustakaan}

Makna itu tidak ada artinya, sampai pada akhirnya dikonstruksi secara interpretatif oleh individu melalui proses interaksi, untuk menciptakan makna yang dapat disepakati secara bersama. Hal ini sesuai dengan tiga dari tujuh asumsi karya Herbert Blumer (1969) dalam West-Turner (2008: 99) di mana asumsi-asumsi itu adalah manusia bertindak terhadap manusia lainnya berdasarkan makna yang diberikan orang lain kepada mereka; makna diciptakan dalam interaksi antar manusia; dan makna dimodifikasi melalui proses interpretatif.

Konsep diri atau Self-Concept, di mana, pada tema interaksi simbolik ini menekankan pada pengembangan konsep diri melalui individu tersebut secara aktif, didasarkan pada interaksi sosial dengan orang lainnya. Tema ini memiliki dua asumsi tambahan, menurut LaRossan \& Reitzes (1993) dalam West Turner (2008: 101), yaitu individuindividu mengembangkan konsep diri melalui interaksi dengan orang lain, dan konsep diri membentuk motif yang penting untuk perilaku.

Hubungan antara kebebasan individu dan masyarakat, di mana asumsi ini mengakui bahwa norma-norma sosial membatasi perilaku tiap individunya, tapi pada akhirnya tiap individu-lah yang menentukan pilihan yang ada dalam sosial kemasyarakatannya. Fokus dari tema ini adalah untuk menjelaskan mengenai keteraturan dan perubahan dalam proses sosial. Asumsi-asumsi yang berkaitan dengan tema ini adalah orang dan kelompok masyarakat dipengaruhi oleh proses budaya dan sosial dan struktur sosial dihasilkan melalui interaksi sosial.

Rangkuman dari hal-hal yang telah 
dibahas sebelumnya mengenai tiga tema konsep pemikiran George Herbert Mead yang berkaitan dengan interaksi simbolik, dan tujuh asumsi-asumsi karya Herbert Blumer (1969) adalah sebagai berikut:

Tiga tema konsep pemikiran Mead, Pentingnya makna bagi perilaku manusia, Pentingnya konsep diri, dan Hubungan antara individu dengan masyarakat.

Tujuh asumsi karya Herbert Blumer (1) Manusia bertindak terhadap orang lain berdasarkan makna yang diberikan orang lain pada mereka; (2) Makna diciptakan dalam interaksi antar manusia; (3) Makna dimodifikasi melalui sebuah proses interpretif; (4) Individu-individu mengembangkan konsep diri melalui interaksi dengan orang lain; (5) Konsep diri memberikan sebuah motif penting untuk berperilaku; (6) Orang dan kelompokkelompok dipengaruhi oleh proses budaya dan sosial; dan (7) Struktur sosial dihasilkan melalui interaksi sosial.

Implikasi dari teori interaksi simbolik dapat dijelaskan dari beberapa teori atau ilmu dan metodologi berikut ini, antara lain: Teori sosiologis modern (Modern Sociological Theory) menurut Francis Abraham (1982) dalam Soeprapto (2007), di mana teori ini menjabarkan interaksi simbolik sebagai perspektif yang bersifat sosial psikologis.

\section{Konsep Diri dan Komponen Konsep Diri}

Konsep diri merupakan keseluruhan persepsi seseorang terhadap diri dan lingkungannya yang terbentuk dari hasil interpretasinya ketika berinteraksi dengan orang lain. Sejalan dengan Brooks (dalam Rakhmat, 2001:74) yang memaparkan bahwa konsep diri merupakan persepsi terhadap diri sendiri, baik fisik, sosial, maupun psikologis, yang didasarkan pada pengalaman-pengalaman dari hasil interaksi dengan orang lain.

Dalam konsep diri, tidak hanya persepsi yang bersifat deskriptif, tetapi juga penilaian terhadap diri sendiri sebagai keseluruhan persepsi seseorang terhadap aspek diri yang meliputi aspek fisik, aspek sosial, dan aspek psikologis, yang didasarkan pada pengalaman dan interaksi individu dengan orang lain yang ada disekitarnya. Manusia sebagai makhluk sosial tidak akan pernah berhenti membutuhkan manusia lain untuk membantunya dalam membangun konsep diri yang lebih baik secara berkelanjutan. Konsep diri merupakan cara pandang penilaian seseorang mengenai dirinya. Konsep diri sangat ditentukan dari beberapa komponen yakni komponen kognitif atau biasa yang kita sebut sebagai citra diri dan komponen afektif atau harga diri.

Konsep diri terdiri atas, Pertama, body image (citra tubuh) adalah sikap individu terhadap dirinya, baik disadari maupun tidak disadari, meliputi persepsi masa lalu atau sekarang mengenai ukuran dan dinamis karena secara konstan berubah seiring dengan persepsi dan pengalaman-pengalaman baru. Body image berkembang secara bertahap selama beberapa tahun, dimulai sejak anak belajar mengenal tubuh dan struktur, fungsi, kemampuan dan keterbatasan mereka. Body image dapat berubah dalam beberapa jam, hari, minggu atau pun bulan tergantung pada stimuli eksterna dalam tubuh dan perubahan aktual dalam penampilan, stuktur dan fungsi (Potter \& Perry, 2005).

Kedua, ideal diri, yaitu persepsi individu tentang bagaimana ia seharusnya bertingkah laku berdasarkan standar pribadi. Standar dapat berhubungan dengan tipe orang yang diinginkan/disukainya atau sejumlah aspirasi, tujuan, nilai yang diraih. Ideal diri akan mewujudkan cita-cita atau pun penghargaan diri berdasarkan normanorma sosial di masyarakat tempat individu tersebut melahirkan penyesuaian diri. Ideal diri berperan sebagai pengatur internal dan membantu individu mempertahankan kemampuan menghadapi konflik atau kondisi yang membuat bingung. Ideal diri penting untuk mempertahankan kesehatan dan keseimbangan mental. Pembentukan ideal diri dimulai pada masa anak-anak dipengaruhi oleh orang yang dekat dengan dirinya yang memberikan harapan atau tuntunan tertentu. Seiring dengan berjalannya waktu individu menginternalisasikan harapan tersebut dan akan membentuk dari dasar ideal diri. Pada usia remaja, ideal diri akan terbentuk melalui proses identifikasi pada orang tua, guru dan teman. Pada usia yang lebih tua dilakukan penyesuaian yang merefleksikan berkurangnya kekuatan fisik dan perubahan peran serta tanggung jawab.

Ketiga, harga diri, yaitu penilaian pribadi terhadap hasil yang dicapai dengan menganalisis seberapa banyak kesesuaian tingkah laku dengan ideal dirinya. Harga diri diperoleh dari diri sendiri dan orang lain yaitu : dicintai, dihormati dan dihargai. Mereka yang menilai dirinya positif cenderung bahagia, sehat, berhasil dan dapat menyesuaikan 
diri. Sebaliknya individu akan merasa dirinya negatif, relatif tidak sehat, cemas, tertekan, pesimis, merasa tidak dicintai atau tidak diterima di lingkungannya (Keliat BA, 2005). Harga diri dibentuk sejak kecil dari adanya penerimaan dan perhatian. Harga diri akan meningkat sesuai dengan meningkatnya usia. Harga diri akan sangat mengancam pada saat pubertas, karena pada saat ini harga diri mengalami perubahan, karena banyak keputusan yang harus dibuat menyangkut dirinya sendiri.

Dengan adanya konsep diri, individu memandang atau menilai dirinya sendiri akan tampak jelas dari seluruh perilakunya. Dengan kata lain, perilaku seseorang akan sesuai dengan cara individu memandang dan menilai dirinya sendiri. Apabila individu memandang dirinya sebagai seorang yang memiliki cukup kemampuan untuk melaksanakan tugas, maka individu itu akan menampakkan perilaku sukses dalam melaksanakan tugasnya. Sebaliknya, apabila individu memandang dirinya sebagai seorang yang kurang memiliki kemampuan melaksanakan tugas, maka individu itu akan menunjukkan ketidakmampuan dalam perilakunya. Proses pembentukan konsep diri menurut Mulyana "Adanya umpan balik orang lain, sehingga dapat membentuk konsep diri dan sangat berperan dalam perilaku individu."

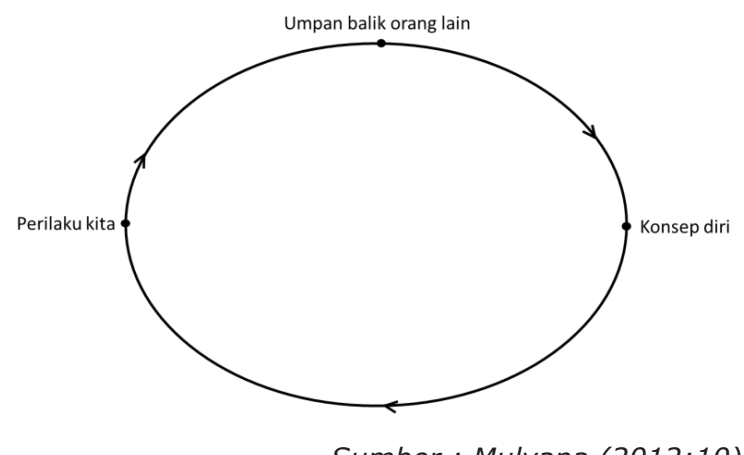

Sumber : Mulyana (2012:10)

Gambar1

Proses Pembentukan Konsep Diri

Hurlock (1990: 238) mengemukakan, konsep diri berperan dalam perilaku individu karena seluruh sikap dan pandangan individu terhadap dirinya akan memengaruhi individu tersebut dalam menafsirkan setiap aspek pengalamannya. Suatu kejadian akan ditafsirkan secara berbeda-beda antara individu yang satu dengan individu yang lain, karena masing-masing individu memunyai pandangan dan sikap berbeda terhadap diri mereka. Tafsiran individu terhadap sesuatu peristiwa banyak dipengaruhi oleh sikap dan pandangan individu terhadap dirinya sendiri. Tafsiran negatif terhadap pengalaman disebabkan oleh pandangan dan sikap negatif terhadap dirinya sendiri, begitu pula sebaliknya.

Selanjutnya, konsep diri dikatakan berperan dalam menentukan perilaku karena konsep diri menentukan pengharapan individu. Menurut beberapa ahli, pengharapan ini merupakan inti dari konsep diri. Pengharapan merupakan tujuan, cita-cita individu yang selalu ingin dicapainya demi tercapainya keseimbangan batin yang menyenangkan. Konsep diri merupakan cara pandang penilaian seseorang mengenai dirinya. Konsep diri sangat ditentukan dari beberapa komponen yakni komponen kognitif atau biasa yang kita sebut sebagai citra diri dan komponen afektif atau harga diri.

Tulisan ini menggunakan pendekatan kualitatif yang berupaya melihat, mengamati, mengelaborasi, dan mengeksplorasi pengalaman dan kesadaran dari para informan yaitu remaja pengguna smartpone sebagai suatu fenomena. Pendekatan ini bertujuan memperoleh pemahaman dan menggambarkan realitas proses konstruksi makna konsep diri remaja dalam interaksi melalui smartphone.

Metode yang digunakan dalam penelitian ini adalah fenomenologi, yang berupaya untuk menelaah tentang kesadaran individu berdasarkan pengalaman yang dimilikinya. Hal ini merujuk pada pernyataan bahwa,

"... phenomenologists explore the struc-
ture of conciousness in human experi-
ence" (... fenomenologis menjelaskan
bahwa struktur kesadaran terletak di pen-
galaman individu) (Creswell, 1998:51).

Pengalaman manusia begitu kompleks sehingga tidak bisa diikat oleh suatu teori tertantu. Bogdan dan Taylor menyatakan bahwa penelitian kualitatif merupakan prosedur yang menghasilkan data-data tertulis atau lisan, yang bersumber dari subjek yang diamati.

Qualitative research is an inquiry process of understanding based on distict methodological traditions of inqury that explore a social or human problem. The researcher build a complex, holostic picture, analyzes words, reports detailed view of importants, and conducts the study in natural setting (Creswell, 1997:15).

Salah satu alasan penting untuk melakukan penelitian kualitatif adalah bahwa 
penelitian tersebut bersifat penyelidikan, topik, atau populasi yang diteliti belum banyak ditulis, dan peneliti harus secara mendetail dan mendalam menangkap dan mendengarkan penjelasan informan tentang berbagai informasi dan membuat gambaran berdasarkan keterangan mereka, atau dengan kata lain, menyusun data hasil penelitiannya dalam bentuk konstruk derajat pertama dan konstruk derajat kedua.

Pendekatan kualitatif digunakan untuk mendapatkan data yang mendalam, suatu data yang mengandung makna. Makna adalah data yang sebenarnya, data yang pasti merupakan suatu nilai di balik data yang tampak. Oleh karena itu, dalam penelitian kualitatif tidak menekankan pada generalisasi, tetapi lebih menekankan pada makna. Dalam penelitian kualitatif, pengumpulan data tidak dipandu oleh teori, tetapi dipandu oleh faktafakta yang ditemukan pada saat penelitian di lapangan. Oleh karena itu, analisis data yang dilakukan bersifat induktif berdasarkan faktafakta yang ditemukan dan kemudian dapat dikonstruksikan menjadi hipotesis atau teori.

Pendekatan fenomenologi mengasumsikan bahwa fenomena adalah pengalaman yang diserap secara sadar, melibatkan intensi atau motif. Fenomenologi digunakan sebagai prosedur penelitian dengan pertimbangan bahwa fenomenologi adalah metode untuk mendapatkan bagaimana fenomena tertentu menjadi pengalaman yang disadari seseorang.

Tabel 1

Kategorisasi Data Motif dan Makna Fitur Smartphone

\begin{tabular}{|c|c|c|c|}
\hline No & Nama Responden & Motif Penggunaan Fitur & Makna Fitur \\
\hline 1. & Fitriyani & $\begin{array}{l}\text { - Sosialisasi/bergaul } \\
\text { - Memudahkan berkomunikasi }\end{array}$ & $\begin{array}{l}\text { Line memiliki keunggulan yang berbeda } \\
\text { karena ada emoticon-nya. }\end{array}$ \\
\hline 2. & Nopita Restiani & $\begin{array}{l}\text { - Sosialisasi/bergaul } \\
\text { - Kebutuhan }\end{array}$ & $\begin{array}{l}\text { Line, BBM, Instagram memiliki } \\
\text { keunggulan dan selalu up-date. }\end{array}$ \\
\hline 3. & Yudha Shihab & $\begin{array}{l}\text { - Ekspresi diri } \\
\text { - Kebutuhan }\end{array}$ & $\begin{array}{l}\text { BBM, Line, Twitter, Facebook dan Game } \\
\text { COC fiturnya lengkap dan gaul. }\end{array}$ \\
\hline 4. & Reva & $\begin{array}{l}\text { - Karena canggih } \\
\text { - Enak buat ngobrol } \\
\text { - Ngisi waktu }\end{array}$ & $\begin{array}{l}\text { Line, BBM, dan Twitter memiliki } \\
\text { keunggulan yang berbeda }\end{array}$ \\
\hline 5. & Dava & $\begin{array}{l}\text { - Lebih murah gak usah beli } \\
\text { pulsa } \\
\text { - Nambah wawasan } \\
\text { - Ada hiburan }\end{array}$ & $\begin{array}{l}\text { - Line lebih up date dan gaul, jadi tidak } \\
\text { ketinggalan jaman } \\
\text { - Ada free call nya }\end{array}$ \\
\hline 6. & Ari & $\begin{array}{l}\text { - Lebih murah } \\
\text { - Ada paketnya }\end{array}$ & $\begin{array}{l}\text { Line dan BBM digunakan keduanya } \\
\text { bersamaan karena teman-teman } \\
\text { menggunakan secara berbeda }\end{array}$ \\
\hline 7. & Syifa Nadia & $\begin{array}{l}\text { - Mengikuti perkembangan } \\
\text { lingkungan } \\
\text { - Bisa bergosip }\end{array}$ & $\begin{array}{l}\text { - Smartphone android lebih enak } \\
\text { karena fiturnya lengkap, Line, BBM, WA, } \\
\text { Path, Facebook, Twitter } \\
\text { - Mempelajari makna dari kata-kata di } \\
\text { timeline yang "kita banget" }\end{array}$ \\
\hline 8. & Aulia Safhira & $\begin{array}{l}\text { - Informasi dapat diperoleh } \\
\text { dengan cepat } \\
\text { - Tidak ketinggalan informasi }\end{array}$ & $\begin{array}{l}\text { Bermanfaat buat grup untuk kerja } \\
\text { kelompok (tugas sekolah) }\end{array}$ \\
\hline 9. & Nadia Miranti & Buat komunikasi sama teman & $\begin{array}{l}\text { - Semua fitur diaktifkan, Line, BBM, WA, } \\
\text { Path Facebook, twitter } \\
\text { - Masing-masing fitur punya manfaatnya }\end{array}$ \\
\hline 10. & Aini Latifah & $\begin{array}{l}\text { - Ikutan teman-teman } \\
\text { - Pengen dibilang gaul dan } \\
\text { kekinian }\end{array}$ & $\begin{array}{l}\text { Fitur yang digunakan Line, Twitter, } \\
\text { Askfm sama Kik, karena manfaatnya } \\
\text { beda-beda }\end{array}$ \\
\hline
\end{tabular}




\section{Hasil Penelitian dan Pembahasan}

Smartphone kini menjadi suatu kebutuhan bagi banyak orang. Tak hanya dari kalangan orang dewasa saja atau para pekerja tingkat menengah ke atas, kini anak muda sekarang pun banyak yang menggunakannya. Beragam golongan menggunakannya. Mulai dari nenek, kakek, ayah, ibu, orang dewasa, para mahasiswa dan mahasiswi, para siswasiswi SMP-SMA, bahkan anak SD. Tidak hanya kalangan profesional, bahkan siswa SMP pun sudah tak asing lagi dengan gadget ini.

Di Indonesia, pengembang Smartphone Research In Motion (RIM) asal Kanada ini tidak membutuhkan iklan untuk memikat pelanggan baru. Produsen smartphone ini pun tidak perlu bersusah payah menawarkan kepada konsumen. Namun, justru konsumenlah yang berburu gadget ini. Seiring berjalannya globalisasi, bisa dibilang sebagian besar remaja sudah menggunakan smartphone. Mereka mendapatkan banyak manfaat, dapat menghubungi teman lebih mudah, mengakses akun jejaring sosial atau blog mereka langsung ditangan mereka sendiri, mencari bahan pelajaran dari situssitus internet tanpa harus merasa kurang nyaman atau terlihat kecil.

Hingga saat ini, smartphone masih menjadi trend para remaja di Indonesia, tak terkecuali di lingkungan sekitar kita. Tren ponsel pintar ini memang telah menguasai pikiran para pelajar dan mahasiswa di Indonesia bahwa No smartphone, No GAUL. Berdasarkan hasil wawancara mendalam, Focus Group Discussion (FGD) dan pengamatan kepada sejumlah narasumber, diperoleh hasil penelitian tentang konsep diri remaja dalam penggunaan smartphone.

\section{Motif Siswa SMP Menggunakan Smartphone dan Memaknai Fiturnya}

Tulisan ini dilakukan dengan pendekatan fenomenologi. Artikel ini mencoba mengurai dan mendeskripsikan fenomena apa saja yang terjadi dalam hal penggunaan smartphone pada tingkat pelajar SMP, makna fiturfitur pada smartphone, motif memilih fitur yang digunakan, dan konsep diri siswa dalam komunikasi sosial. Motif remaja menggunakan smartphone antara lain adalah untuk sosialisasi diri, bergaul, membuka wawasan, eksistensi diri, dan agar dapat ikut mengikuti membicarakan topik-topik aktual di kalangan remaja. Setelah dilakukan reduksi fenomenologis, reduksi eidetis dan reduksi transendental, diperoleh kategorisasi data hasil penelitian yang dituangkan pada Tabel 1 .

\section{Konsep Diri Remaja dalam Komuni- kasi Sosial melalui Smartphone}

Hasil wawancara, FGD dan observasi menunjukkan kategorisasi konsep diri remaja SMP yang unik, karena berbeda dengan konsep diri sebelum remaja menggunakan smartphone. Demikian juga pola atau kebiasaan komunikasi sosial remaja SMP memperlihatkan pola yang berbeda antara komunikasi sosial secara langsung dengan pola komunikasi sosial melalui smartphone. Secara rinci kategorisasi tersebut digambarkan dalam Tabel 2.

\section{Penilaian Konsep Diri Remaja di Mata Kelompok Sebaya}

Data empirik menunjukkan bahwa di samping konsep diri remaja (berdasarkan persepsi diri), ditemukan juga konsep diri remaja hasil penilaian atau persepsi teman sebaya dari komunikasi sosial melalui smartphone, yang ternyata tidak selalu sama persis dengan konsep diri remaja yang sesungguhnya. Demikian juga mengenai fitur yang ada di smartphone, menggambarkan adanya jenis fitur-fitur tertentu yang dipandang lebih mewakili atau merepresentasikan konsep diri remaja. Secara rinci, kategorisasinya dapat dilihat pada Tabel 3.

Masa remaja bisa disebut dengan masa transisi, karena disebut anak-anak sang remaja itu tidak mau, namun disebut dewasa juga tidak terima. Remaja adalah masa transisi dimana nilai-nilai dalam kehidupan tengah berkecamuk antara pencarian jati diri dan mengikuti tren yang update saat ini. masa remaja adalah masa yang mereka anggap bebas dalam bertindak, tapi beberapa mahasiswa saya justru sudah mempunyai konsep diri yang kuat, yang bisa terlihat dari sikap dan tutur bahasa mereka.

Salah satu contoh konsep diri yang kuat bagi remaja adalah mereka menyadari bahwa di usia mereka lah saatnya menuntut ilmu hingga mereka benar-benar fokus dalam menjalankan peran tersebut. Fokus belajar adalah salah satu dari beberapa pentingnya konsep diri bagi remaja. Blumer (1966) mengingatkan, lingkungan harus senantiasa berada pada kondisi yang sesuai kebutuhan siswa, agar menjadi faktor penumbuh dorongan-dorongan untuk berprestasi, Wachidah dalam Mimbar, Vol. 25, No. 1 Tahun 2009). 
Tabel 2

Kategorisasi Penjelasan Konsep Diri Remaja dalam Komunikasi Sosial melalui Smartphone

\begin{tabular}{|c|c|c|c|c|}
\hline No & $\begin{array}{l}\text { Nama } \\
\text { Responden }\end{array}$ & Penjelasan Konsep Diri & $\begin{array}{l}\text { Pola Komunikasi } \\
\text { Sosial }\end{array}$ & Keterangan \\
\hline 1. & Fitriyani & $\begin{array}{l}\text { Saya lebih banyak teman } \\
\text { dalam pergaulan }\end{array}$ & $\begin{array}{l}\text { Lebih mudah } \\
\text { berkomunikasi dengan } \\
\text { teman }\end{array}$ & \begin{tabular}{|l} 
Fitur yang ada \\
mendukung \\
konsep diri
\end{tabular} \\
\hline 2. & Nopita Restiani & $\begin{array}{l}\text { Lebih mudah berkomunikasi } \\
\text { dan lebih gaul }\end{array}$ & $\begin{array}{l}\text { Lebih suka gambar } \\
\text { emoticon-nya karena } \\
\text { lebih bermakna }\end{array}$ & $\begin{array}{l}\text { Fitur yang ada } \\
\text { mendukung } \\
\text { konsep diri }\end{array}$ \\
\hline 3. & Yudha Shihab & $\begin{array}{l}\text { Melalui game dapat } \\
\text { berkomunikasi dengan } \\
\text { teman }\end{array}$ & $\begin{array}{l}\text { Lebih suka bermain } \\
\text { game }\end{array}$ & $\begin{array}{l}\text { Fitur yang ada } \\
\text { mendukung } \\
\text { konsep diri }\end{array}$ \\
\hline 4. & Reva & $\begin{array}{l}\text { Saya menjadi mudah } \\
\text { berteman } \\
\text { Saya membantu teman } \\
\text { untuk lebih dekat }\end{array}$ & $\begin{array}{l}\text { - Berbagi banyak hal } \\
\text { dengan teman dengan } \\
\text { cara menulis ekpsresi } \\
\text { diri } \\
\text { - Lebih hati hati kalau } \\
\text { komunikasi di media } \\
\text { sosial }\end{array}$ & $\begin{array}{l}\text { Fitur yang ada } \\
\text { mendukung } \\
\text { konsep diri }\end{array}$ \\
\hline 5. & Dava & $\begin{array}{l}\text { Mendekatkan diri dengan } \\
\text { teman jadi lebih mudah, } \\
\text { karena awalnya susah dekat }\end{array}$ & $\begin{array}{l}\text { Lebih suka gambar, hasil } \\
\text { gambar saya posting ke } \\
\text { teman-teman }\end{array}$ & $\begin{array}{l}\text { Fitur yang ada } \\
\text { mendukung } \\
\text { konsep diri }\end{array}$ \\
\hline 6. & Ari & $\begin{array}{l}\text { Saya dinilai "gimana" (lebih } \\
\text { hebat dibanding aslinya. } \\
\text { Pen) oleh teman-teman di } \\
\text { fitur }\end{array}$ & $\begin{array}{l}\text { Lebih suka gambar } \\
\text { untuk mengekspresikan } \\
\text { diri }\end{array}$ & $\begin{array}{l}\text { Tidak ada } \\
\text { Fitur yang ada } \\
\text { menghambat } \\
\text { konsep diri }\end{array}$ \\
\hline 7. & Syifa Nadia & $\begin{array}{l}\text { Saya tadinya orangnya } \\
\text { tertutup, tapi dengan } \\
\text { smartphone jadi sadar harus } \\
\text { lebih terbuka, jadi meski } \\
\text { tidak terlalu bisa akrab, tapi } \\
\text { belajar saling sapa dengan } \\
\text { teman }\end{array}$ & $\begin{array}{l}\text { - Melihat dulu event } \\
\text { yang ada, baru buka } \\
\text { chat group dan personal } \\
\text { - Lebih suka menulis }\end{array}$ & $\begin{array}{l}\text { Tidak ada } \\
\text { Fitur yang ada } \\
\text { menghambat } \\
\text { konsep diri }\end{array}$ \\
\hline 8. & Aulia Safhira & $\begin{array}{l}\text { Waktu tidak menggunakan } \\
\text { smartphone tidak terbuka } \\
\text { sama teman, sekarang jadi } \\
\text { bisa lebih terbuka }\end{array}$ & $\begin{array}{l}\text { - Membuka chat group } \\
\text { dulu, baru personal } \\
\text { - Lebih suka } \\
\text { menggambar }\end{array}$ & $\begin{array}{l}\text { Tidak ada } \\
\text { fitur yang ada } \\
\text { menghambat } \\
\text { konsep diri }\end{array}$ \\
\hline 9. & Nadia Miranti & $\begin{array}{l}\text { Kadang di Chat rame, tapi } \\
\text { pas ketemu langsung diem- } \\
\text { diem aja karena malu } \\
\text { Kalau di Line sering dibilang } \\
\text { aktif dan banyak omong } \\
\text { Kalo di Instagram dibilang } \\
\text { "jaim" (jaga image) }\end{array}$ & $\begin{array}{l}\text { - Biasanya diawali } \\
\text { dengan membicarakan } \\
\text { topik yang sedang } \\
\text { hangat, dari situ akan } \\
\text { rame muncul pandangan } \\
\text { tiap orang } \\
\text { - Langsung buka Chat }\end{array}$ & $\begin{array}{l}\text { Tidak ada } \\
\text { Fitur yang ada } \\
\text { menghambat } \\
\text { konsep diri }\end{array}$ \\
\hline 10. & Aini Latifah & $\begin{array}{l}\text { Aku kan orangnya cerewet, } \\
\text { jadi ya di Sphone juga } \\
\text { dibilang cerewet }\end{array}$ & $\begin{array}{l}\text { - Membahas topik yang } \\
\text { asyik dan kekinian } \\
\text { - Langsung buka Chat }\end{array}$ & $\begin{array}{l}\text { Tidak ada } \\
\text { Fitur yang ada } \\
\text { menghambat } \\
\text { konsep diri }\end{array}$ \\
\hline
\end{tabular}


Tabel 3

Kategorisasi Penilaian Konsep Diri Remaja di Mata Kelompok Sebaya

\begin{tabular}{|c|c|c|c|c|}
\hline No & $\begin{array}{c}\text { Nama } \\
\text { Responden }\end{array}$ & $\begin{array}{l}\text { Penilaian Konsep Diri di } \\
\text { Mata Kelompok Sebaya }\end{array}$ & $\begin{array}{c}\text { Fitur yang paling } \\
\text { Mendukung Konsep } \\
\text { Diri }\end{array}$ & Keterangan \\
\hline 1. & Fitriyani & $\begin{array}{l}\text { - Saya dipandang mudah } \\
\text { bergaul dan } \\
\text { - Saya dipandang penyabar } \\
\text { dan mudah bergaul }\end{array}$ & $\begin{array}{l}\text { BBM, Line, Twitter, } \\
\text { Facebook, dan } \\
\text { Instagram }\end{array}$ & $\begin{array}{l}\text { Fitur yang ada } \\
\text { mendukung konsep } \\
\text { diri }\end{array}$ \\
\hline 2. & $\begin{array}{l}\mathrm{N} \text { o p i } \mathrm{t} \text { a } \\
\text { Restiani }\end{array}$ & $\begin{array}{l}\text { Saya orangnya terbuka } \\
\text { berkat fitur-fitur yang } \\
\text { ada dan lebih bisa } \\
\text { mengekspresikan diri }\end{array}$ & $\begin{array}{l}\text { BBM, Line, Twitter, } \\
\text { Facebook dan } \\
\text { Instagram }\end{array}$ & $\begin{array}{l}\text { Fitur yang ada } \\
\text { mendukung konsep } \\
\text { diri }\end{array}$ \\
\hline 3. & Yudha Shihab & $\begin{array}{l}\text { Saya dipandang lebih } \\
\text { tertutup dan pendiam }\end{array}$ & $\begin{array}{c}\text { BBM, Line, Twitter, } \\
\text { Facebook dan Game } \\
\text { COC }\end{array}$ & $\begin{array}{l}\text { Bisa berbagi banyak } \\
\text { hal melalui game }\end{array}$ \\
\hline 4. & Reva & $\begin{array}{l}\text { - Saya dipandang bisa } \\
\text { berteman secara terbuka } \\
\text { - Saya juga dipandang } \\
\text { temperamental, tapi ingin } \\
\text { berubah }\end{array}$ & Line dan Twitter dan WA & $\begin{array}{l}\text { Bisa berbagi banyak } \\
\text { hal dengan teman }\end{array}$ \\
\hline 5. & Dava & $\begin{array}{l}\text { Teman memandang saya } \\
\text { secara berbeda antara di } \\
\text { SPhone dengan ketemu } \\
\text { langsung, yaitu orang yang } \\
\text { tahan banting dibanding } \\
\text { teman-teman }\end{array}$ & Line dan Twitter & $\begin{array}{l}\text { Fitur yang ada } \\
\text { mendukung konsep } \\
\text { diri }\end{array}$ \\
\hline 6. & Ari & $\begin{array}{l}\text { - Saya dipandang mudah } \\
\text { bergaul berkat SPhone } \\
\text { - Saya dipandang penyabar } \\
\text { dan tidak mudah marah }\end{array}$ & Grup BBM dan Line & $\begin{array}{l}\text { Gaya bahasa di group } \\
\text { temen lebih bebas }\end{array}$ \\
\hline 7. & Syifa Nadia & $\begin{array}{l}\text { - Saya orangnya tertutup, } \\
\text { tapi sekarang lebih bisa } \\
\text { terbuka } \\
\text { - Saya ingin lebih dikenal } \\
\text { - Saya punya kepribadian } \\
\text { ganda, antara tertutup } \\
\text { sama pengen belajar } \\
\text { terbuka } \\
\text { - Banyak yang bilang saya } \\
\text { tempat curhat dan mak } \\
\text { comblang }\end{array}$ & Line dan face book & $\begin{array}{l}\text { - Fitur facebook bisa } \\
\text { digunakan untuk } \\
\text { meminta pendapat } \\
\text { orang lain } \\
\text { - Tapi dengan line } \\
\text { bisa lebih selektif } \\
\text { memilih teman dan } \\
\text { pendapatnya }\end{array}$ \\
\hline 8. & Aulia Safhira & $\begin{array}{l}\text { - Awalnya tidak terbuka, } \\
\text { tapi sejak pakai SPhone jadi } \\
\text { lebih terbuka } \\
\text { - Saya lebih pendiam dan } \\
\text { kehabisan kata kalu ketemu } \\
\text { langsung }\end{array}$ & Line & $\begin{array}{l}\text { Line membuat lebih } \\
\text { gamang terbuka }\end{array}$ \\
\hline 9. & Nadia Miranti & $\begin{array}{l}\text { - Saya orangnya aktif alias } \\
\text { banyak omong kalau di Line } \\
\text { - Saya dibilang jaim sama } \\
\text { orang yang belum kenal } \\
\text { dekat }\end{array}$ & Instragram dan Line & $\begin{array}{l}\text { Ketika foto yang } \\
\text { diupload di instragram } \\
\text { bagus, jadi banyak } \\
\text { yang suka,jadi } \\
\text { banyak followers, jadi } \\
\text { bisa eksis } \\
\end{array}$ \\
\hline 10. & Aini Latifah & $\begin{array}{l}\text { - Saya orangnya rame kalo } \\
\text { di SPhone, tapi diem kalo } \\
\text { ketemu langsung karena } \\
\text { pemalu } \\
\text { - Pengen sekali jadi orang } \\
\text { yang asik dan kekinian }\end{array}$ & Line & $\begin{array}{l}\text { Kalau Chat Line lebih } \\
\text { akrab lagi sama } \\
\text { teman }\end{array}$ \\
\hline
\end{tabular}


Beberapa orangtua pasti merasa kesulitan memotivasi anak remaja mereka untuk belajar karena begitu banyaknya halhal yang menggoda seperti gadget, televisi dan social media yang tengah booming saat ini. Dengan konsep diri yang kuat bahwa saat ini lah, saatnya belajar dan menuntut ilmu untuk masa depan kelak, maka sang remaja telah menanamkan pentingnya masa depan dan pengembangan diri mereka. Fungsi komunikasi sebagai komunikasi sosial setidaknya mengisyaratkan bahwa komunikasi itu penting untuk membangun konsep diri kita, aktualisasi diri, untuk kelangsungan hidup, untuk memperoleh kebahagiaan, terhindar dari tekanan dan ketegangan, antara lain lewat komunikasi yang bersifat menghibur, dan memupuk hubungan hubungan orang lain. Melalui komunikasi dapat bekerja sama dengan anggota masyarakat (keluarga, kelompok belajar, teman, dan sebagainya) untuk mencapai tujuan bersama.

Pembentukan Konsep Diri. Konsep diri adalah pandangan kita mengenai diri kita, dan itu hanya bisa kita peroleh lewat informasi yang diberikan orang lain kepada kita. Melalui komunikasi dengan orang lain, kita belajar bukan saja mengenai siapa kita, namun juga bagaimana kita merasakan siapa kita. Anda mencintai diri Anda bila Anda telah dicintai; Anda berpikir Anda cerdas bila orang-orang sekitar Anda menganggap anda cerdas; Anda merasa tampan atau cantik bila orang-orang sekitar Anda juga mengatakan demikian.

George Herbert Mead (dalam Rakhmat, 1994) mengistilahkan significant others (orang lain yang sangat penting) untuk orangorang di sekitar kita yang mempunyai peranan penting dalam membentuk konsep diri kita. Ketika kita masih kecil, mereka adalah orang tua kita, saudara-saudara kita, dan orang yang tinggal satu rumah dengan kita.

Richard Dewey dan W.J. Humber (1966) menamai affective others, untuk orang lain yang dengan mereka kita mempunyai ikatan emosional. Dari merekalah, secara perlahanlahan kita membentuk konsep diri kita. Selain itu, terdapat apa yang disebut dengan reference group (kelompok rujukan) yaitu kelompok yang secara emosional mengikat kita, dan berpengaruh terhadap pembentukan konsep diri kita. Dengan melihat ini, orang mengarahkan perilakunya dan menyesuaikan dirinya dengan ciri-ciri kelompoknya.

Pernyataan eksistensi diri. Orang berkomunikasi untuk menunjukkan dirinya eksis. Inilah yang disebut aktualisasi diri atau lebih tepat lagi pernyataan eksistensi diri. Fungsi komunikasi sebagai eksistensi diri terlihat jelas misalnya pada penanya dalam sebuah seminar. Meskipun mereka sudah diperingatkan moderator untuk berbicara singkat dan langsung ke pokok masalah, penanya atau komentator itu sering berbicara panjang lebar menguliahi hadirin, dengan argumen-argumen yang terkadang tidak relevan.

Untuk kelangsungan hidup, memupuk hubungan, dan memperoleh kebahagiaan. Sejak lahir, kita tidak dapat hidup sendiri untuk mempertahankan hidup. Kita perlu dan harus berkomunikasi dengan orang lain, untuk memenuhi kebutuhan biologis kita seperti makan dan minum, dan memenuhi kebutuhan psikologis kita seperti sukses dan kebahagiaan.

Para psikolog berpendapat, kebutuhan utama kita sebagai manusia, dan untuk menjadi manusia yang sehat secara rohaniah, adalah kebutuhan akan hubungan sosial yang ramah, yang hanya bisa terpenuhi dengan membina hubungan yang baik dengan orang lain.

Abraham Moslow menyebutkan bahwa manusia punya lima kebutuhan dasar: kebutuhan fisiologis, keamanan, kebutuhan sosial, penghargaan diri, dan aktualisasi diri. Kebutuhan yang lebih dasar harus dipenuhi terlebih dahulu sebelum kebutuhan yang lebih tinggi diupayakan. Kita mungkin sudah mampu kebutuhan fisiologis dan keamanan untuk bertahan hidup. Kini kita ingin memenuhi kebutuhan sosial, penghargaan diri, dan aktualisasi diri. Kebutuhan ketiga dan keempat khususnya meliputi keinginan untuk memperoleh rasa lewat rasa memiliki dan dimiliki, pergaulan, rasa diterima, memberi dan menerima persahabatan.

Komunikasi akan sangat dibutuhkan untuk memeroleh dan memberi informasi yang dibutuhkan, untuk membujuk atau memengaruhi orang lain, mempertimbangkan solusi alternatif atas masalah kemudian mengambil keputusan, dan tujuan-tujuan sosial serta hiburan.

Komunikasi ekspresif. Komunikasi berfungsi untuk menyampaikan perasaanperasaan (emosi) kita. Perasaan-perasaan tersebut terutama dikomunikasikan melalui pesan-pesan nonverbal. Perasaan sayang, peduli, rindu, simpati, gembira, sedih, takut, prihatin, marah, dan benci dapat disampaikan lewat kata-kata, namun bisa disampaikan 
secara lebih ekpresif lewat perilaku nonverbal. Seorang ibu menunjukkan kasih sayangnya dengan membelai kepala anaknya. Orang dapat menyalurkan kemarahannya dengan mengumpat, mengepalkan tangan seraya melototkan matanya, mahasiswa memprotes kebijakan penguasa negara atau penguasa kampus dengan melakukan demontrasi.

Konsep diri siswa SMP (Sekolah Menengah Pertama) Negeri di Kota Bandung terhadap penggunaan smartphone, berdasarkan hasil penelitian, dapat terlihat bahwa kebanyakan para siswa menggunakan smartphone dan alasan dapat mempermudah dalam berkomunikasi. Selain itu, penggunaan smartphone dapat memfasilitasi remaja dalam berkomunikasi, karena memiliki fungsi pembentukan konsep diri, fungsi eksistensi diri, fungsi memupuk hubungan dan memperoleh kebahagiaan, serta fungsi ekspresif. Fitur yang paling digunakan dalam smartphone adalah BBM, Line, Twitter, Facebook dan Instagram dimana kebanyakan aplikasi yang digunakan juga dipakai oleh orang lain terutama teman sebaya. Jadi pilihan menggunakan fitur sangat terhantung pada pilihan teman sebaya dalam komunikasi sosial remaja.

Ketika sedang menggunakan smartphone merek 'SAMSUNG GALAXI tipe J atau Grand' kebanyakan anak SMP dalam menggunakannya memiliki pola yang sama ataupun rutin dilakukan setiap harinya tanpa melupakan urutan dari penggunaan smatphone yang ada. Ada yang memulai dari membuka grup BBM, lalu Line, ke Twitter, WhatsApp, Facebook, sampai pada aplikasi lain, seperti Instagram, dan Path. Pola komunikasi teman sebaya remaja juga mirip satu sama lain. Fakta ini menunjukkan adanya suatu pola kebiasaan komunikasi sosial yang melekat dan termapankan. Menurut mereka dengan menggunakan smartphone itu menjadikan mereka dipermudah dalam berhubungan ataupun berkomunikasi dengan teman-teman mereka dan menjadi bagian yang tidak akan bisa dilepaskan dari aktivitas mereka setiap harinya.

Remaja SMP yang menjadi informan umumnya melihat diri mereka dalam menggunakan fitur ini sebagai bagian yang tak terpisahkan dari komunitasnya, juga fiturfitur dalam smartphone menjadi alat penting dalam bersosialisasi ataupun bergaul dengan teman temannya yang tidak dasari oleh niat lain. Anggapan mereka dalam melihat dari dampak keuntungan menggunakan smartphone adalah untuk dapat sering bisa berkomunikasi dengan para temannya dimana membicarakan hal-hal yang dianggap seru dan disukai. Yang bisa dilihat dari bagaimana para anak SMP ini menempatkan dirinya dalam menggunakan dan harapan yang diinginkan dirinya dari penilaian temannya sebagai sesorang yang dianggap mudah bergaul dan dapat bisa diajak berbicara dan mengobrol dengan baik.

Kemudian yang bisa terlihat juga, bahwa dalam penggunaan smartphone di kalangan anak SMP yang ada, fitur dalam smartphone yang paling dianggap selalu bisa mengekspresikan dirinya adalah fitur yang sering dan biasa digunakan kebanyakan adalah fitur-fitur yang juga dipakai oleh lingkungannya yakni teman-teman sebaya mereka sebagai pengguna smartphone, dan sesama remaja sebaya yang menyukai topik yang sama pula. Penggunaan smartphone yang memperlihatkan dukungan bagi konsep diri adalah fitur yang memiliki keunggulan emoticon, gambar, serta alat-alat ekspresi lainnya, yakni BBM, Line dan Game Clash Of Clans yang ada dalam smartphone. Sedangkan fitur yang sering dianggap kurang mendukung bagi konsep dirinya adalah fiturfitur yang jarang digunakan secara pribadi oleh pengguna smartphone ataupun teman teman pengguna remaja lainnya, seperti Facebook dan Whatsapp.

Kondisi faktual, telah memperlihatkan bahwa penggunaan fitur yang digunakan oleh para anak SMP ini digunakan ataupun di-download oleh para pengguna smartphone ini dipakai karena kebutuhan diri mereka untuk berkomunikasi. Tujuan dan manfaat fitur tertentu akan menentukan pilihan remaja. Dan ketika fitur tertentu banyak digunakan oleh teman-teman mereka yang sering diajak mengobrol dan mempunyai kepentingan yang sama dalam membicarakan topik menarik dan penting, seperti tugas sekolah atau isu remaja aktual, maka remaja pengguna smartphone ini menggunakan fitur tersebut. Misalnya, ketika seorang pengguna smartphone memilki teman-teman yang memang kebanyakan menggunakan fitur smartphone BBM maka dia sebagai seorang teman yang mempunyai kebutuhan untuk mengobrol akan menggunakan fitur yang sama sehingga dirinya terdukung. Sedangkan penggunaan fitur smartphone yang kurang mendukung dirinya adalah fitur yang kebanyakan sudah tidak digunakan oleh para pengguna smartphone sehingga diri mereka tidak terdukung. 
Penggunaan fitur smartphone yang digunakan pola gaya bahasa yang digunakan kebanyakan anak SMP ini menulis dengan gaya biasa saja meski kadang-kadang sering ditambahi dalam penulisan kata menggunakan angka didalam penulisannya, serta pada penggunaan fitur smartphone juga tidak diawali dari sebuah topik dalam melakukan perbincangan dengan teman-temannya, tetapi memang obrolan itu dimulai biasa saja. Yang kemudian juga dalam penyampaian kata kata dalam penggunaan fitur sering disisipkan penggunaan emoticon seperti sedih, tertawa, dan lain-lain yang mendukung pengekspresikan kata kata yang sedang disampaikan. Penggunaan fitur-fitur tersebut akan sangat mendukung seseorang terbangun dirinya dalam melakukan komunikasi.

Semua hal di atas dilakukan adalah untuk bisa menampilkan dirinya dapat mendapatkan hal positif dari dirinya dilihat oleh orang lain, dan harapan yang paling utama diharapkan oleh para pengguna smartphone adalah bagaimana bisa menambah teman teman sebanyak-banyaknya dengan penggunaan smartphone dimana dari semua hal itu akan menjadikan kebanggaan untuk dirinya.

Konsep diri merupakan keseluruhan persepsi seseorang terhadap diri dan lingkungannya yang terbentuk dari hasil interpretasinya ketika berinteraksi dengan orang lain. Sejalan dengan Brooks (dalam Rakhmat, 2001: 74) yang memaparkan bahwa konsep diri merupakan persepsi terhadap diri sendiri, baik fisik, sosial, maupun psikologis, yang didasarkan pada pengalaman-pengalaman dari hasil interaksi dengan orang lain. Dalam konsep diri tidak hanya persepsi yang bersifat deskriptif, tetapi juga penilaian terhadap diri sendiri sebagai keseluruhan persepsi seseorang terhadap aspek diri yang meliputi aspek fisik, aspek sosial, dan aspek psikologis, yang didasarkan pada pengalaman dan interaksi individu dengan orang lain yang ada disekitarnya. Manusia sebagai makhluk sosial tidak akan pernah berhenti membutuhkan manusia lain untuk membantunya dalam membangun konsep diri yang lebih baik secara berkelanjutan.

\section{Simpulan dan Saran}

Fenomena penggunaan smartphone pada pelajar SMP Negeri, yaitu faktor kebutuhan dan faktor gaya hidup. Kebutuhan akan informasi dalam dunia global telah mendorong para siswa untuk menggunakannya, serta gaya hidup pada masyarakat modern telah menjadi faktor yang kedua. Adapun dampak sosial penggunaan smartphone pada pelajar ini terdiri dampak positif dan dampak negatif. Dampak yang postif yaitu meningkatkan rasa percaya diri, lebih memudahkan komunikasi, dan memperoleh banyak teman.

Penggunaan smartphone dikalangan anak SMP yang ada, fitur dalam smartphone yang paling dianggap selalu bisa mengekspresikan dirinya adalah fitur yang sering digunakan kebanyakan adalah fitur-fitur yang memang kebanyakan dipakai oleh lingkungannya di mana di sini dimaksudkan adalah teman-teman sebaya mereka sebagai pengguna smartphone dan sesama anak-anak yang menyukai hal bagi yang sama pula.

Motif remaja menggunakan smartphone antara lain adalah untuk sosialisasi diri, bergaul, membuka wawasan, eksistensi diri, dan agar dapat ikut mengikuti membicarakan topik-topik aktual di kalangan remaja.

Konsep diri siswa SMP (Sekolah Menengah Pertama) Negeri di Kota Bandung terhadap penggunaan smartphone, berdasarkan hasil penelitian, dapat terlihat bahwa kebanyakan para siswa menggunakan smartphone dan alasan dapat mempermudah dalam berkomunikasi. Selain itu, penggunaan smartphone dapat memfasilitasi remaja dalam berkomunikasi, karena memiliki fungsi pembentukan konsep diri, fungsi eksistensi diri, fungsi memupuk hubungan dan memperoleh kebahagiaan, serta fungsi ekspresif.

Banyak fitur yang tidak cocok bagi pelajar. Smartphone lebih cocok untuk pebisnis dengan aktifitas padat sehingga memerlukan sebuah gadget yang lebih mengutamakan konektifitas online dengan kliennya.

Pelajar lebih konsumtif. Tarif berlangganan yang disediakan provider untuk smartphone cukup mahal padahal fitur-fitur yang digunakan hanya untuk berkonektivitas dengan teman-temannya saja.

Filter diri pelajar masih labil untuk perkembangan teknologi sekelas smartphone. Kemudahan akses online yang disajikan di ponsel ini menyebabkan pergaulan online dan akses online pelajar yang menggunakannya semakin tidak terkendali. Mereka selalu ingin tahu dan mencoba. Dampak positif dapat memperoleh infformasi dengan cepat, meningkatkan rasa percaya diri, dan 
berkomunikasi.

\section{Daftar Pustaka}

Creswell, John. W. (1994). Research Design Qualitative \& Quantitative Approaches. Sage Publications Inc.

http: //chochoirunnisa. wordpress. com/2012/12/14/dampak-dan-pengaruhbagi-pengguna-smartphone/

Keliat, Budi Anna, Dkk. (2005). Proses Keperawatan Kesehatan Jiwa Edisi 2. Jakarta.

Littlejohn, S.W., Gray, R. (2001). Theories of Human Communication (7th ed. Belmont: Wadsworth Publishing Company.

Mulyana, Deddy. (2012). Ilmu Komunikasi, Suatu Pengantar. PT. Remaja Rosdakarya, Bandung.

Mulyana, Deddy. (2003). Metode Penelitian Kualitatif: Paradigma Baru Ilmu Komunikasi dan Ilmu Sosial Lainnya. Bandung: PT. Remaja Rosdakarya.

Potter \& Perry. (2005). Buku Ajar Fundamental Keperawatan. Jakarta.

Rakhmat, Jalaluddin. (2005). Metode Penelitian Komunikasi. PT Remaja RosdaKarya. Bandung.

Rakhmat, Jalaluddin. (2009). Psikologi Komunikasi. PT Remaja RosdaKarya. Bandung. PT Remaja RosdaKarya. Bandung.

Wachidah dalam Jurnal Mimbar, Volume 25, No. 1 Tahun 2009, hal. 7

West, Richard \& Lynn H. Turner. (2008). Pengantar Teori Komunikasi Analisis dan Aplikasi. (Terj. Maria Natalia Damayanti Maer). Penerbit Salemba Humanika. Jakarta. 